\title{
40. GRAVITY TECTONICS ON A PASSIVE MARGIN: DEEP SEA DRILLING PROJECT SITE 415 IN RELATION TO REGIONAL SEISMIC DATA
}

\author{
Ilfryn Price, ${ }^{1}$ The British Petroleum Co. Ltd., Britannic House, Moor Lane, London, EC2Y9BU, \\ United Kingdom
}

\begin{abstract}
Lithologic repetition and deformation of the cored sediments indicate that DSDP Hole 415A penetrated a 450-meter Upper Cretaceous allochthonous unit with several imbricate repetitions of a Cenomanian shale-and-carbonate sequence above a décollement of Albian and Cenomanian shale. This unit is expressed on multichannel seismic profiles as an interval of chaotic interval signal. Its upper surface is deformed by folds which predate the overlying Tertiary turbidites. Some of these folds maintain a harmonic profile in the sequence beneath the allochthonous unit, whereas others are restricted to the top of the unit. Although some folds are asymmetric, we cannot recognize a consistent vergence.

Profiles beneath the continental slope east of Site 415 indicate that the drilled sequence is only the distal portion of a much more widespread feature. The equivalent sequence beneath the lower slope is thcker and is cut by several major, landward-dipping thrust faults across which there is a minimum of $20 \mathrm{~km}$ of overthrusting. The thrusts have a north-south strike, as do the disharmonic folds within each individual thrust sheet. Both folds and faults are refolded by a series of east-west-trending folds parallel to the Atlas tectonic trend.

The displaced unit is not present beneath the upper slope, where it passes laterally into a prominent angular unconformity. This zone represents the source area for the overthrust masses. Onshore geological evidence indicates the emergence of the western High Atlas Mountains during Late Cretaceous times, and the allochthon is interpreted as an associated belt of gravity-driven overthrusts refolded by the last phases of this tectonism. Its scale is comparable with that of some overthrust zones in orogenic chains, and its existence on a passive margin may be important to the interpretation of exposed nappe complexes. Uplift of the western Atlas, gravity sliding, folding of the allochthon, and the onset of Canary Islands volcanism can be explained by sinistral strike-slip faulting along the South Atlas fault during Late Cretaceous time.
\end{abstract}

\section{INTRODUCTION}

One of the most intriguing, and unexpected, results from Leg 50 of the Deep Sea Drilling Project/International Phase of Ocean Drilling was the discovery, at Site 415 (Figure 1), of several repetitions of a thin Cenomanian mudstone-carbonate sequence, interpreted as a Late Cretaceous gravity-slide complex (Site 415 report, this volume). Regional seismic evidence, including multichannel profiles, some of which were unavailable before Leg 50, indicates that Hole 415A penetrated only the distal part of a very extensive and commonly much thicker Upper Cretaceous allochthon. This paper presents the seismic evidence for the extent and structure of the complex and assesses its place in the evolu-

\footnotetext{
${ }^{1}$ Present address: British Petroleum Development Co. Ltd., Farburn Industrial Estate, Dyce, Aberdeen, Scotland.
}

tion of the Moroccan continental margin. It is, I believe, the first description of the internal structure of such a feature on a "passive" continental margin. The allochthon compares, in size, to many exposed thrust complexes and may well have analogs in various orogenic belts.

\section{Tectonic Setting}

Site 415 lies at the intersection of two prominent topographic and tectonic trends (Figure 1); the High Atlas orogen and the igneous ridge of the inner Canary Islands. Both trends are reflected in the structure of the allochthon, and all three features may be related (see below). East of Site 415 the succession in the coastal Essaouira basin (Ambroggi, 1963; Société Cherifienne des Pétroles, 1966) is affected by the western end of the High Atlas foldbelt (Ager, 1974), one of the principal orogenic components of the Alpine system. North of the 


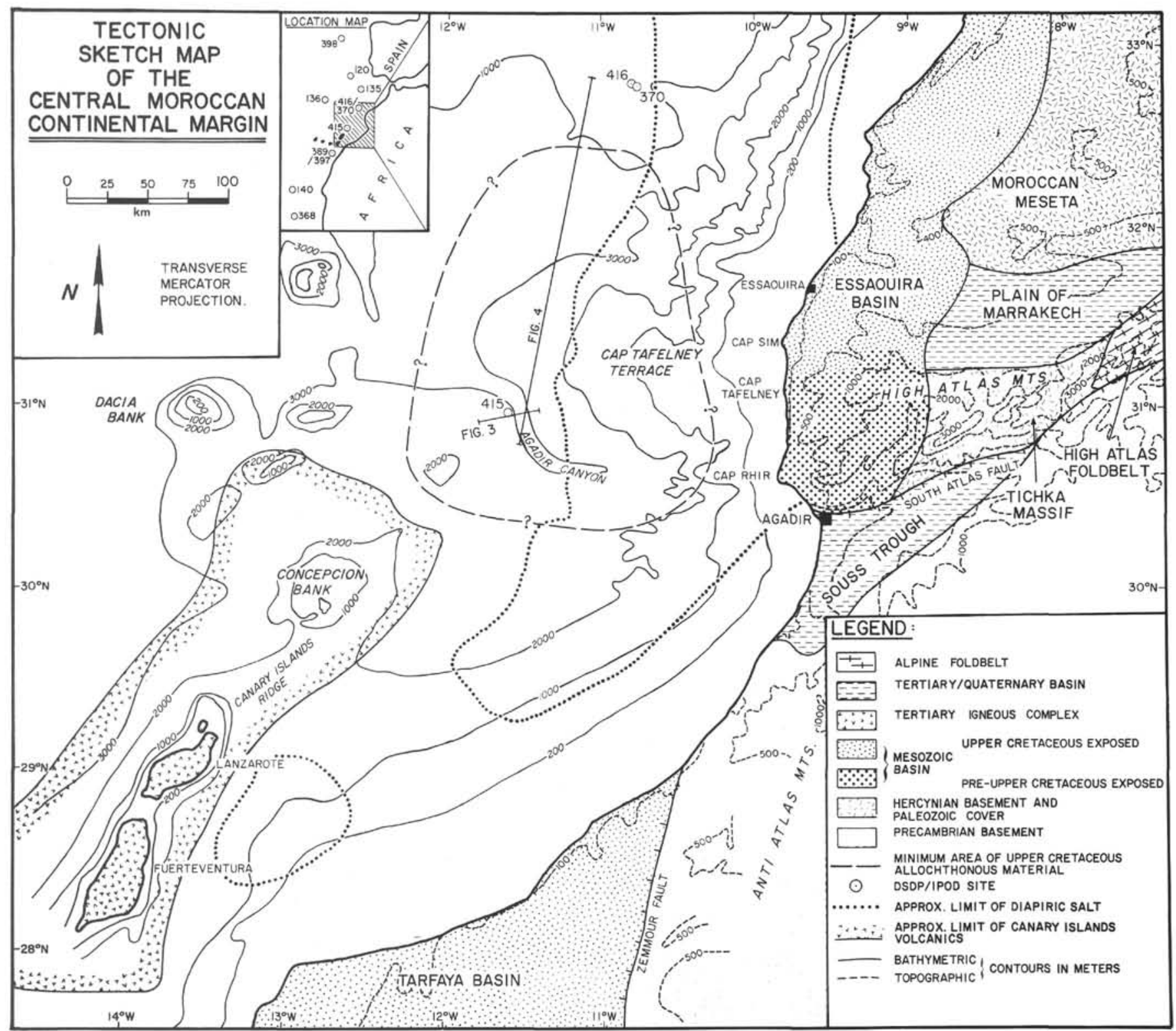

Figure 1. Tectonic sketch map of the central Moroccan continental margin, showing the location of Leg 50 and previous DSDP drilling sites. Bathymetry is taken from NIO plotting sheets. Topographic contours and onshore geology are simplified from 1:500,000 maps by the Moroccan Geological Survey and from maps by Dillon and Sougy (1974) and Ager (1974). Site 415 falls at the intersection of two very distinctive topographic trends. Offshore geology is modified from published maps (Dillon and Sougy, 1974; Beck and Lehner, 1974; Grunau et al., 1975; Uchupi et al., 1976) on the basis of regional reconnaissance seismic profiling. The Upper Cretaceous allochthon is discussed in this paper. The limit of Canary Islands volcanism is mapped as the approximate extent of a volcanic apron sufficiently thick to obscure any underlying sedimentary sequence.

western High Atlas, in the Sillon Nord Atlasique (Ambroggi, 1963), only Upper Cretaceous and younger rocks are exposed (1:500,000 geological map of Morocco; Ager, 1974). To the east these are buried by Tertiary and Quaternary deposits of the Plain of Marrakech (Figure 1). By contrast, in the western Atlas, Lower Cretaceous and older strata crop out beneath a thin Quaternary cover. The Mesozoic succession wedges out eastward against the western flank of a Hercynian metamorphic complex, the Tichka Massif, which separates the western Atlas from the true, Alpide, High Atlas foldbelt (Dillon and Sougy, 1974; Evans et al., 1974; Warme et al., 1974; du Dresnay, 1975). The southern boundary of the High Atlas is the South Atlas fault, dubbed the true geological boundary of Europe and Africa by Ager (1974). Unfortunately the Mesozoic history of this fault is apparently still unknown. It separates the western High Atlas from the Souss trough (Figure 1), a Late Cretaceous and Tertiary sub-basin of the Essaouira basin. 
The prominent ridge of the High Atlas reappears beneath the continental slope as a bathymetric high (Figure 1) for which the name Cap Tafelney terrace is suggested and used here. The southeastern boundary of the terrace is defined by the Agadir Canyon, within which Site 415 was drilled. South of the site the Canary Islands ridge (Uchupi et al., 1976) extends northeastward from the inner Canary Islands, Fuerteventura and Lanzarote, through Concepcion Bank. The core of this ridge is an igneous massif with a Tertiary volcanic apron (Beck and Lehner, 1974; Grunau et al., 1976) which is presumably a continuation of the igneous complexes exposed on Fuerteventura and Lanzarote. The age of the oldest igneous rocks on these islands is not known (Mitchell-Thomé, 1976). However Robertson and Stillman (in press) have recently demonstrated that, on Fuerteventura, middle Cretaceous (?Albian or Cenomanian) sedimentary rocks, conformably overlain by undated basaltic lavas, were folded prior to intrusion by middle Eocene or Paleocene (?) basic dikes.

\section{Evidence for Gravity Slides in Hole 415A}

The geologic interpretation of Hole $415 \mathrm{~A}$ is a joint conclusion of the Leg 50 shipboard scientific party (Site 415 report, this volume). It is briefly summarized here (Figure 2). Cores 415A-7 to 415A-14 contained middle to Upper Cretaceous calcareous and dolomitic shales with interbedded recrystallized limestone and dolostone, and very thin, silt-grade calciturbidites. This material is extensively deformed, with microfolds of several centimeters, amplitude, some of which are offset along small-scale shear zones. Dips on bedding planes within a single core range from $0^{\circ}$ to $45^{\circ}$ to the core barrel. The degree of deformation varies inconsistently from core to core. For example, Core 415A-9 contains folds with amplitudes up to $30 \mathrm{~cm}$, whereas Core $415 \mathrm{~A}-10$ is relatively undisturbed. Shale, in the lower cores, is highly fissile, and harder beds are cut by joint planes dipping at about $45^{\circ}$ to the bedding plane. En echelon tensional fractures, filled by calcite, indicate brittle fracture of the shale in Core 415A-14. Thus the lithologic evidence suggests a slumped, stratigraphically jumbled succession. However, the gamma-ray log shows an otherwise unsuspected ordering in this sequence. The tool was run inside the drill pipe, and its response was accordingly muted. Nonetheless the interval from 491 to 780 meters shows at least four repetitions of a 57 -meterthick log signature (Figure 2). Such an exact repetition can only be explained by invoking either depositional or tectonic lithologic cyclicity. Even without the possibility of stratigraphic repetition, such accurate cyclicity as a primary feature of the sediments involved would be difficult to envisage. The combination of lithologic and log evidence indicates repetition due to a series of discrete thrust slices rather than chaotic slumps.

Below 780 meters the gamma-ray log shows no cyclicity, nor is there evidence of stratigraphic repetition. The highly fractured Cenomanian and Albian shales recovered in Cores 415A-13 and 14 (Figure 2) can, however, be interpreted as the décollement for the overlying imbricate slices. Evidence from Core 415A-15 establishes the need for a décollement beneath the thrust sequence. It contains undisturbed Albian marlstone with a sand-grade calciturbidite bed similar to those recovered at Sites 370 (Shipboard Scientific Party, 1977) and 416 (Site 416 report, this volume). Thus Hole 415A must have passed through the Upper Cretaceous allochthon into undeformed underlying sediments.

We cannot be sure of the succession within a single thrust slice and the log does not pinpoint thrust planes. Although each core nominally comes from a 9.5 -meter interval, each was in fact taken after drilling 70 meters with an open core barrel (Site 415 report, this volume) and could therefore include material from anywhere in that 70 meters. Judging from the limited material available, upper-Albian and lower-Cenomanian sediments are rather argillaceous with thin, silt-grade turbidite laminae, whereas upper-Cenomanian deposits are more calcareous. If the natural gamma radiation is taken as an indicator of shale content, each repeated cycle (Figure 2) can be subdivided into a uniform calcareous interval (lower gamma signal) and a section dominated by shale with some interbedded carbonate. The latter is more likely to represent the interval which would most readily be exploited by thrust planes. Thus one should probably place the break between log cycles within the interval of higher signal. Figure 2 illustrates a possible reconstruction of the imbricate sequence using this reasoning. Some cores must be relocated to achieve this-or any other-reconstruction, and no unique solution can be found. The lack of a precise definition of the stratigraphic succession, however, in no way detracts from the main point: the proven presence of an imbricated allochthonous sequence which must have reached its present position in Turonian or Senonian time, presumably under the influence of gravity, as there is no regional evidence for compressive deformation of sufficient magnitude to produce such a complex.

\section{SEISMIC EVIDENCE AND INTERPRETATION}

\section{Data Sources}

Much of the evidence discussed here is based on multichannel seismic profiles recorded by the companies and institutions acknowledged elsewhere in the paper. Line locations for the data are still confidential; consequently no composite track chart is included. The locations of profiles reproduced in Figures 3 and 4 are shown on Figure 1. Reconnaissance profiles in water deeper than about 2000 meters were supplemented by a semidetailed survey over the Cap Tafelney terrace.

In preparing the structural map (Figure 7) the multichannel data were supplemented by single-channel DSDP underway profiles recorded by the Glomar Challenger during Legs 41,47 , and 50 (Figures 7 and 8). Although the horizon mapped is often at the extreme limit of resolution of these profiles, there are sufficient ties to multichannel lines to provide reasonable control over the interpretation of the DSDP records. 


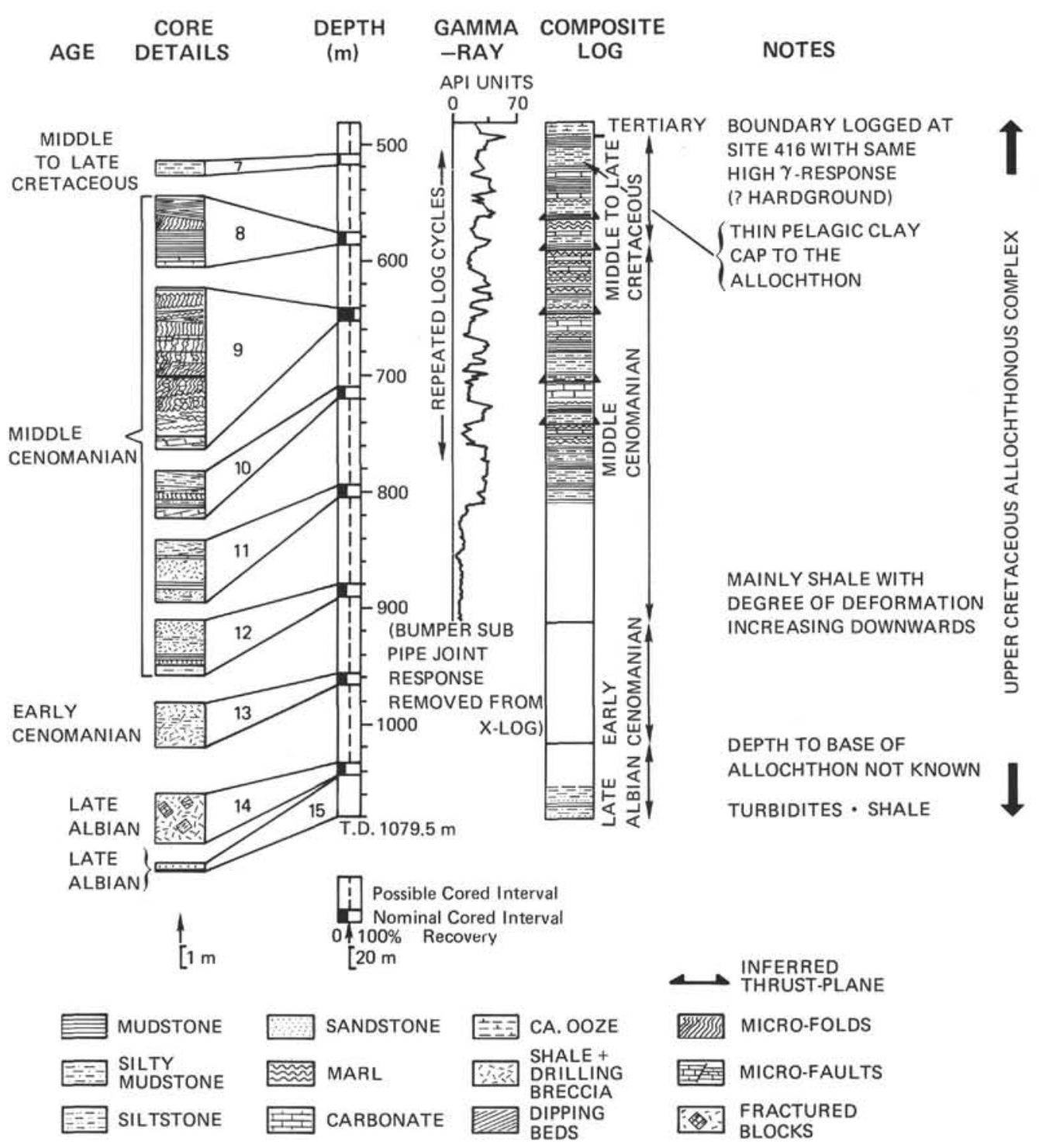

Figure 2. Summary log of the Cretaceous section in Hole 415A. The left-hand column shows the age, lithology, and degree of deformation of each core. These cores were nominally taken from the intervals shown, but could in fact have come from anywhere over a 70-meter interval. The third column shows the Schlumberger gamma-ray log which was run through the drill pipe. Below 810 meters the signal is masked by the thicker walls of the bottom hole assembly. Sharp-peaked minima recorded every 10 meters, owing to pipe joints, have been removed from the log trace shown. The repeating gamma-ray cycles are clear. Repetition can be established, whichever point is chosen as the start of the cycle. The right-hand column shows an interpreted section, as explained in the text. Other interpretations are possible, but must still involve lithologic and stratigraphic repetition. The gamma-ray peak at 491 meters is interpreted as a hard ground at the Cretaceous-Tertiary boundary. An equivalent peak was logged at Site 416.

\section{Seismostratigraphy of the Allochthon Near Site 415}

Figure 3 shows a portion of a multichannel seismicreflection profile through Site 415 . Prominent reflections are identified using color names rather than letters, for consistency with presite surveys, shipboard practice, and site reports for Leg 50 . The red horizon can be traced northward to Site 416 (Figure 1) on two separate surveys (e.g., Figure 4). It has been unequivocally identified at that site using bulk-density and sonic logs and corresponds to the contact of Paleocene pelagic marl and late Paleocene turbidites. The Cretaceous-Tertiary hiatus, 19 meters below the red horizon at Site 416 , is marked by a prominent gamma-ray peak. 


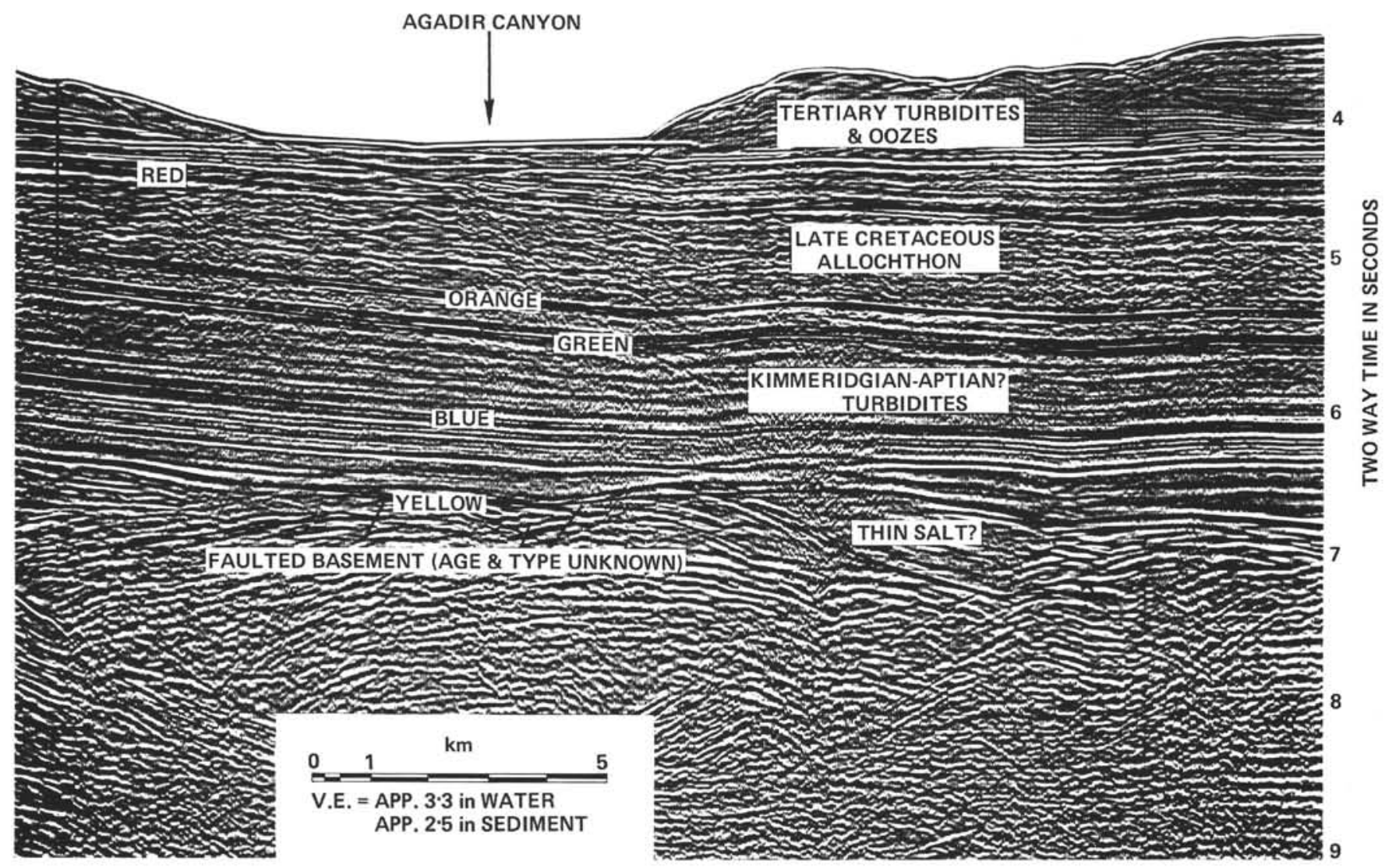

Figure 3. Portion of a multichannel seismic profile (24-fold filtered stack) through Site 415 (Figure 1), reproduced by permission of Phillips Petroleum Co. Ltd. and partners. The reflectors shown, which are those used for shipboard work and initial cruise summaries, were first defined on a nearby profile which was not subsequently released for publication in this volume. The allochthonous sequence corresponds to an interval of chaotic internal signal with well-layered reflectors above and below. This interval thins westward and finally gives way to a thin (100 ms) layered interval between the red and orange horizons.

An equivalent peak occurs on the gamma-ray log in Hole 415A (Figure 2). As the thickness of the Paleocene marls is fairly constant and is less than the resolution of the profiling system used, the red horizon can be considered as effectively marking the base of the Tertiary.

Below the red horizon is a clearly defined interval, $620 \mathrm{~ms}^{2}$ thick at Site 415 , with a chaotic ${ }^{3}$ seismic signal. Occasional discontinuous reflections within this interval appear to dip eastward at a much steeper angle than do the well-layered reflectors above and below. Chaotic reflections are characteristic of-although by no means

\footnotetext{
${ }^{2}$ All seismic depths and thicknesses are quoted in seconds (s) or milliseconds (ms) of two-way travel time. The approximation $1 \mathrm{~ms}=$ $1 \mathrm{~m}$ will serve as an approximate depth conversion in the sediments involved. Accurate velocity data are presented by Boyce (this volume).

${ }^{3}$ Internal reflection character of seismic intervals is described using the terminology proposed by Sangree et al. (1976).
}

always confined to-slump zones (e.g., Sangree et al., 1976). In this instance the chaotic interval can only correspond to the Upper Cretaceous allochthon.

I interpret the orange reflector, at the base of the chaotic interval, as the top of the undisturbed Lower Cretaceous turbidites below the allochthon. This horizon is, in fact, truncated by the red horizon south and west of Site 416 (Figure 4). The underlying green horizon cannot be precisely correlated with any reflector at Site 416 , but its approximate equivalent has been identified (the olive reflector on Figure 4). This olive reflector must lie near the top of the Lower Cretaceous turbidite sequence (Site 416 report, this volume), but we cannot equate it with a visible lithologic break.

Drilling at Site 416 stopped a few meters short of the blue horizon. We know therefore that the well-layered interval between the green and blue horizons represents a Kimmeridgian to Aptian-Albian flysch, but the blue 


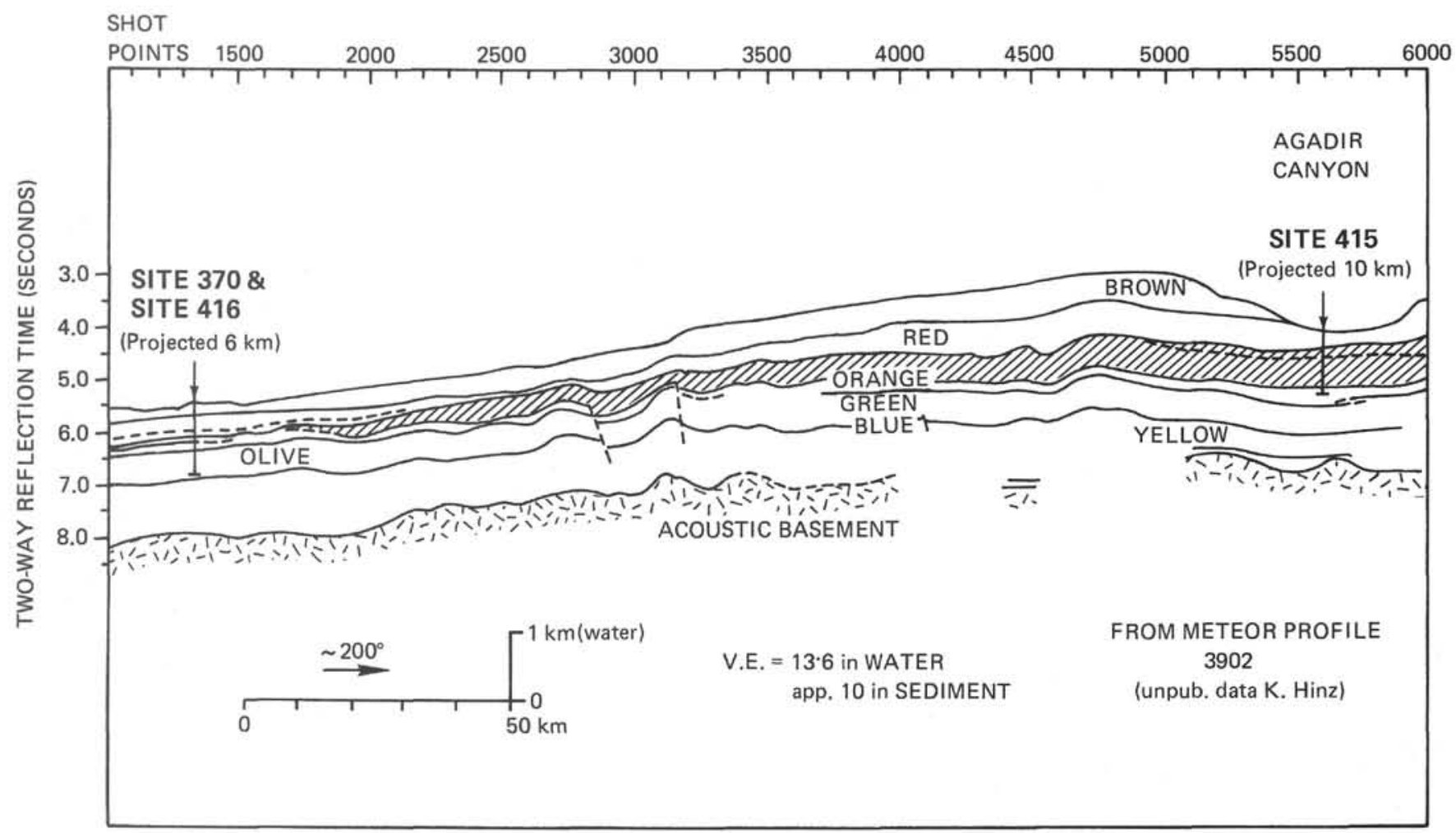

Figure 4. Line drawing of the R/V Meteor 3902 6-channel profile between Sites 415 and 416 (Figure 1). The chaotic interval is hachured. It thins northward and finally disappears completely as the underlying orange reflector is truncated by the red reflector near Site 416. Two types of fold are visible at the red level, some folds being repeated at the orange and deeper horizons, whereas other folds are restricted to the red horizon, with no deeper expression.

horizon itself is undated. Regionally, blue is an important reflector which onlaps Oxfordian(?) oceanic basement to the west (Lancelot and Winterer, this volume). The prominent "yellow event" at the base of the layered sequence (Figure 3 ) is undated. It may be laterally equivalent to the top of Triassic(?) evaporites and I interpret it as representing the "break-up" event for this section of the continental margin. The nature of the crust beneath Site 415 remains enigmatic.

\section{Regional Variation in the Red to Orange Interval \\ Oceanward Thinning}

The interval of chaotic reflection (red to orange reflectors; Figure 3 ) is easily recognized on multichannel seismic profiles, but its implications were not appreciated prior to Leg 50. It covers an area of at least 10,000 $\mathrm{km}^{2}$ (below and Figure 1). The southern boundary is poorly defined owing to a lack of data and to confusion caused by diapiric salt (Figure 1). The interval thins westward from Site 415 (Figure 3) and passes into a thin (about $100 \mathrm{~ms}$ ) unit of parallel reflectors about $50 \mathrm{~km}$ west of the site. There is a similar thinning to the north (Figure 4) where red becomes a slight angular unconformity. Limited Late Cretaceous erosion is indicated by the truncation of the underlying orange reflector.

\section{Overthrusting Beneath Cap Tafelney Terrace}

East of Site 415 the changes in the seismic records are more dramatic (Figure 5). Seismic lines in this area were not available at the time of Leg 50 . Had they been, the drilling results might not have come as such a surprise. A few kilometers east of the site, red abruptly assumes a pronounced ridge-and-swell topography (Figure 5). The lack of any surface expression of this topography and the thinning of the Tertiary sequence over the high suggests a Late Cretaceous deformation, as does the occasional onlap of the oldest Tertiary reflections against the highs. The post-red sequence is characterized by lowangle truncations and lobate reflection packages as might be expected in a turbidite sequence.

The eastern flanks of individual swells continue, as strong reflections, beneath the next swell to the east. These features, which are below the red horizon, show none of the pronounced relief of that surface (Figure 5). They are interpreted as major slip planes along which successive swells have overthrust each other in a westerly, or downslope, direction. The complete profile (Figure 6) shows three such overthrusts, with a net shortening of at least $20 \mathrm{~km}$. The chaotic signal from within each thrust sheet (Figure 5) suggests severe internal deformation. The maximum thickness of an individual sheet is about $800 \mathrm{~ms}$, i.e., 750 to 1000 meters. 


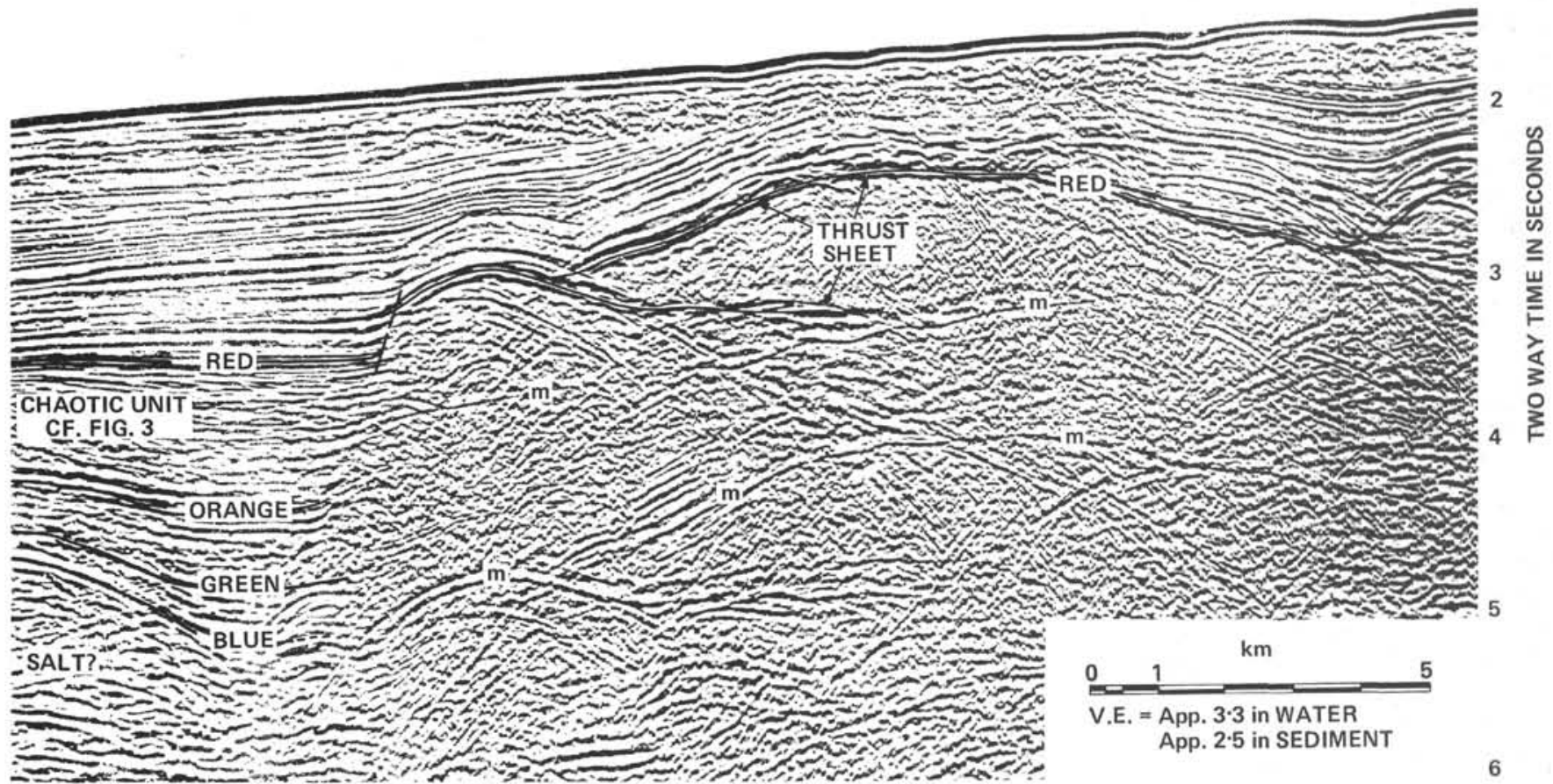

Figure 5. Segment of a multichannel seismic profile across the lower continental slope northeast of Site 415 (Figure 1), reproduced by permission of Phillips Petroleum Co. Ltd.. and partners. The reflectors shown can be correlated with the line shown on Figure 3. The red horizon becomes a high-relief surface over-lying a zone of chaotic reflection which is cut by prominent reflectors terminating in lows on the red surface. These are interpreted as thrust planes along which successive slices of the allochthonous complex have overthrust each other in a westward direction. Multiple reflections are denoted " $m$."

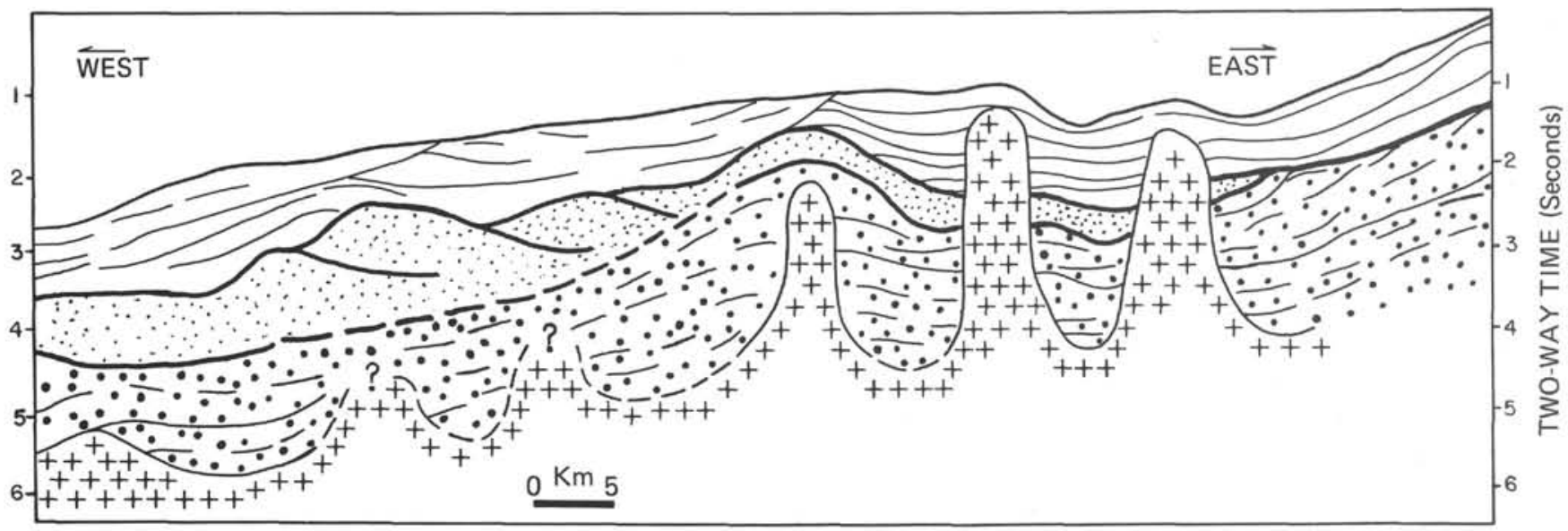

$\begin{aligned} \text { VE }= & 6.6 \text { in WATER } \\ & \text { APP } 5 \text { in SEDIMENT }\end{aligned}$

$\square$ TERTIARY $\because$ JURASSIC/L. CRETACEOUS

U. CRETACEOUS $\left.{ }_{+}^{+}\right]$TRIASSIC (?) SALT
ALLOCHTHON

Figure 6. Line drawing of a profile across the slope of Cap Tafelney terrace. There are several overthrusts of the type shown on Figure 5. To the east the chaotic zone below the red horizon thins and finally becomes an angular unconformity pierced by major salt diapirs. Diapirs of such magnitude are not visible within the area covered by the allochthon, although elsewhere they extend throughout the diapir fields shown on Figure 1. 
The base of the allochthon is not always visible, and underlying reflections are obscured by a combination of diapiric salt and dispersal of seismic energy within the deformed interval. Farther east, where the interval thins, there is clearly more relief on the red horizon than on the base of the chaotic unit. Although this relationship may be partially explained by velocity differences between the allochthonous material and the overlying Tertiary sediment, almost certainly the top of the allochthon is more severely deformed than its base, a relationship which confirms a décollement at the base of the deformed interval.

Beneath the lower slope, therefore, the sequence equivalent to the Upper Cretaceous allochthon at Site 415 is a westward-directed overthrust complex of considerable magnitude, presumably formed by downslope, gravity-driven movement. This interval thins eastward (Figure 6) and finally disappears below the upper slope, where the red horizon becomes an angular unconformity which outcrops at the seabed close to the present shelf break. The unconformity has been detected on single-channel profiles by Summerhayes et al. (1971), whose dredge-haul results confirm that it separates the Lower Cretaceous and Tertiary. The area of the unconformity is therefore interpreted as the source of the allochthon from which sediments were removed by gravity sliding.

Where the allochthon is thin or absent, large diapirs pierce virtually to the sea floor. These presumably originate from Triassic salt as do those onshore (Société Cherifienne des Pétroles, 1966). Beneath the lower slope, where the allochthon is thicker, the diapirs are more subdued and have not penetrated the red horizon. The possibility of a genetic link between salt diapirism and gravity sliding is considered subsequently.

\section{Structure of the Red Horizon}

\section{The Thrust Complex}

The seismic character of the allochthon allows two subdivisions to be recognized, the complex of major overthrusts beneath Cap Tafelney terrace (Figures 5 and 6 ) and the distal apron (Figures 3 and 4), where discrete overthrusts are not visible. In the first zone, the topography of the red surface has a complex "eggbox" pattern reminiscent of an interference figure produced by two intersecting sets of folds. Individual thrust at red (e.g., Figure 5) can be correlated in a system of three major thrust sheets over the whole terrace (Figure 7), with several subsidiary sheets of local extent. Each thrust is complemented by an anticlinal fold, on the red horizon, with an axial trace essentially parallel to the fault. The thrusts, as might be expected, exploit either the intervening synclines or the steeper, eastern limbs of the anticlines. These north-south-trending, or $\mathrm{F}^{1}$, folds are refolded, as apparently are some of the thrusts, by a second, $\mathrm{F}^{2}$, series of folds with axial traces trending essentially east-west. The effects of the $\mathrm{F}^{2}$ folding are more pronounced in the outermost, or western thrust sheets. Inner sheets appear to be relatively unaffected and may even override $\mathrm{F}^{2}$ folds, a relationship which implies coeval folding and thrusting.

Along the southern flank of the terrace, both the thrusts and the $\mathrm{F}^{1}$ fold axes swing eastward along the trend of the Agadir Canyon (Figure 7). The structure of the allochthon is particularly complex in this area, with several small normal faults at the level of the red horizon. Both thrusts and $\mathrm{F}^{1}$ folds may be offset along small sinistral faults, but this cannot be proved. Erosion of the allochthon within the Agadir Canyon only adds to the problems of interpretation posed by the structural complexity. The structure south of the canyon is unknown.

\section{The Distal Apron}

This is the portion of the allochthon drilled at Site 415. It consists of a series of thin imbricate slices with no sign of the massive overthrusts of the thrust complex. The relief on the red horizon, while still pronounced, is much more subdued than it is farther east. Figure 7 shows the extent of folding at the red level. The greater vertical exaggeration of the single-channel records serves to emphasize the asymmetric profile of many of these folds (Figure 8). Unfortunately there were insufficient data to map these folds with enough accuracy to determine their vergence.

Multichannel profiles (e.g., Figure 4) again reveal two types of folds at the red horizon. Some are clearly disharmonic with respect to older reflectors, in which case the relief on the red is more pronounced than on the orange or deeper horizons. Others are parellel and maintain their form at all levels below the red horizon. Higher events are not folded to the same extent, although there is some degree of draping. The Paleogene sequence thins over, and onlaps against, anticlines, proving that both types of folding resulted from Late Cretaceous deformation.

The disharmonic folds are interpreted as gravity features related to the sliding which produced the $\mathrm{F}^{1}$ folds beneath Cap Tafelney terrace. The parallel folds are unlikely to represent salt swells, as they extend well beyond the limits of salt diapirism and the seismic profiles show no sign of salt cores. Moreover, they are linear rather than domelike. Features which can be confidently identified as salt swells are restricted to a small area immediately west of the overthrust complex (e.g., Figure 5). Hence I interpret the parallel folds as tectonic features produced by compressional stress.

The relationship of the two fold types is not entirely clear, owing to gaps in the multichannel seismic coverage. However, disharmonic folds on the flanks of larger parallel structures suggest that some sliding, at least, was associated with compressive folding. The axial traces of the major parallel folds trend almost east-west (about $100^{\circ}$; Figure 7) and can be correlated with the axes of $\mathrm{F}^{2}$ folds beneath Cap Tafelney terrace.

South of Site 415 the structure of the red horizon is much simpler, with a single, large parallel anticline striking about $030^{\circ}$, i.e., parallel to the Canary Islands tectonic trend. The lower Tertiary sequence thins over this structure, but onlap of basal Tertiary reflectors can- 


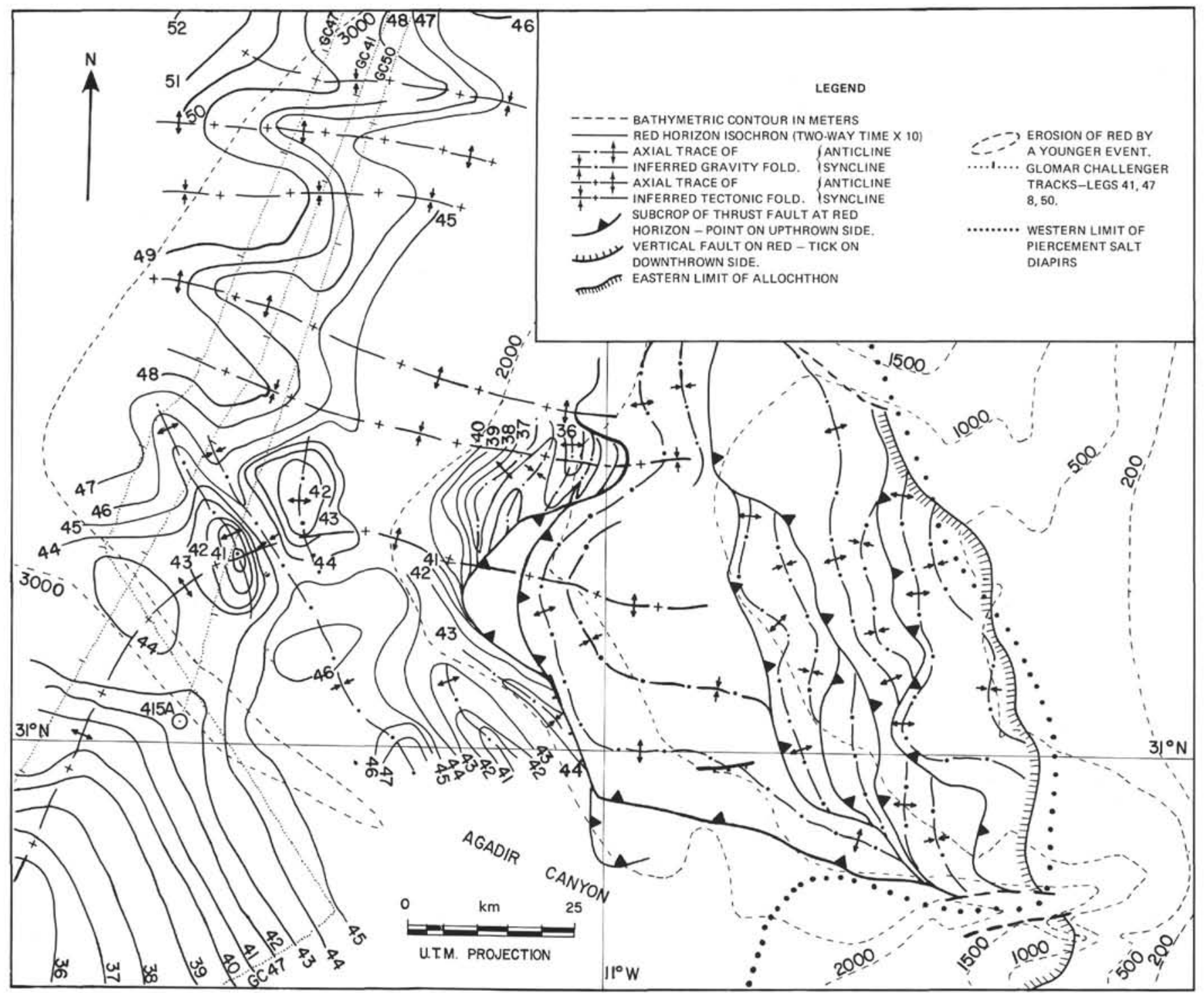

Figure 7. Structural map of the red horizon, compiled using multichannel reconnaissance seismic profiles and singlechannel Glomar Challenger profiles (GC, 41, 47, 50; cf. Figure 8). In the east, the distal portion of the allochthon is folded about a correlatable series of east-west-trending folds. South of the Agadir Canyon the structure is less complex and the strike changes to parallel the trend of the Inner Canary Islands. The contours shown are in time; Figures 4 and 8, however, illustrate that the folds are real and are not an artifact of a sea-bed topography.

not be demonstrated, and the structure has some Tertiary expression. It is, therefore, probably of early Tertiary age and thus somewhat younger than the folding north of Site 416. The possibility of Late Cretaceous folding cannot, however, be discounted. In view of the equivalent strikes, this structure is best explained as a product of uplift associated with igneous intrustion along the Canary Islands Ridge.

\section{DISCUSSION}

\section{Origin of the Allochthon}

\section{The Problem}

Seismic evidence indicates two components in the Late Cretaceous allochthon drilled at Site 415: an inner overthrust complex and a distal thrust apron. Westward-directed gravity sliding off the upper slope, and perhaps the outer shelf, was accompanied by gentle but persistent compressive folding about axes striking between $100^{\circ}$ and $110^{\circ}$ across the outer margin. An explanation of the sliding must provide a mechansim for the uplift of the inner margin and, ideally, for the compressive folding. Of the two possibilities, namely salt diapirism beneath the upper slope and epeirogenic uplift along the Atlas trend, I prefer the latter for the reasons given below.

\section{The Diapirism Hypothesis}

Clearly some spatial relationship exists between salt diapirism and the allochthon. Major piercements with a 


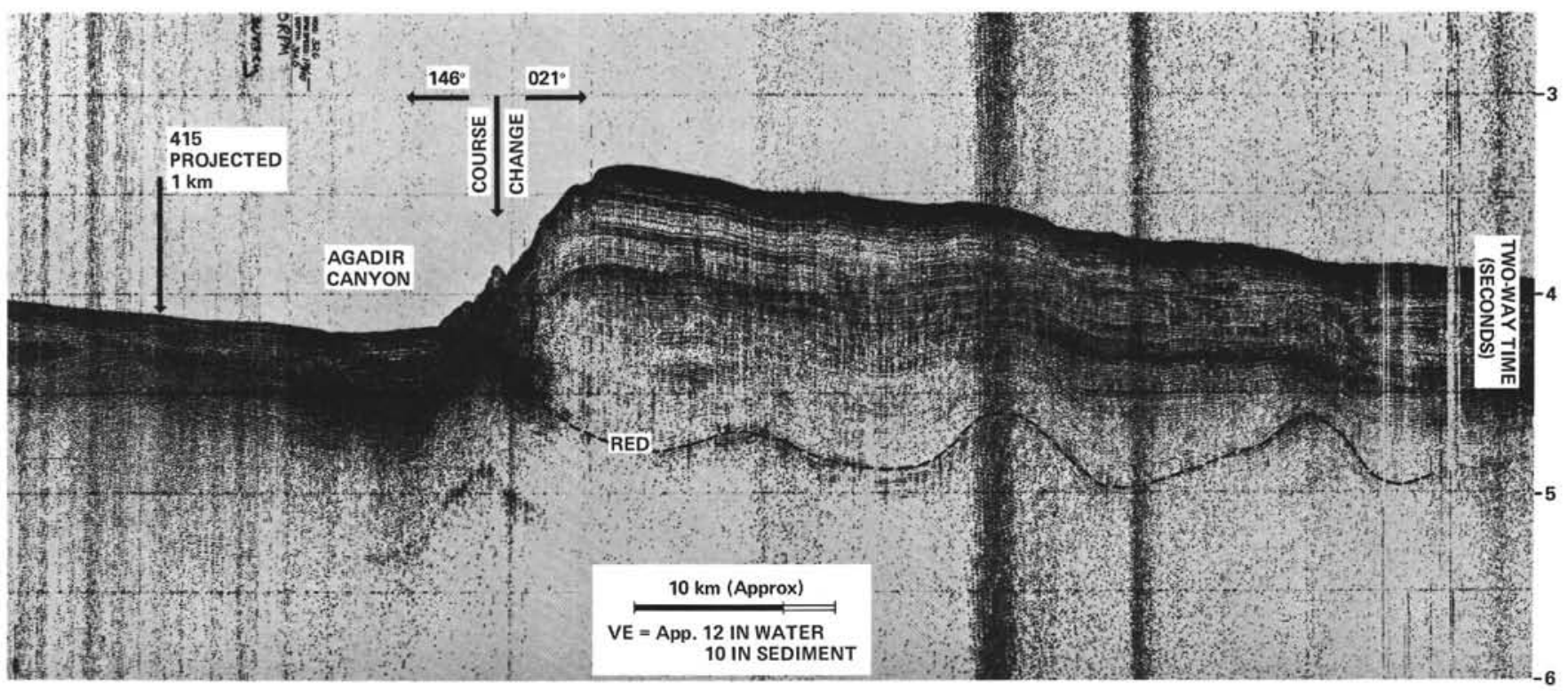

Figure 8. Sketch map showing inferred geography and tectonic events of the Atlas-Canary trend in Late Cretaceous time. The compressional folding described here and tensional volcanism on Fuerteventura (Robertson, in press) can be explained by sinistral shear along a curved continuation of the South Atlas fault. The folds north of this line would correspond to the "Ist-order drag-folds" of Moody and Hill (1956). Onshore geography is simplified from maps by the Société Cheriffienne des Péetroles (1966). Onshore fold trends (JA = Jebel Amsitten; IT = Ida-ouTanane) are from Ambroggi (1963). These are probably Tertiary structures, although there is evidence of some Cretaceous movement (see text). The offshore limit of the exposed West Atlas high is placed at the Cretaceous-Tertiary unconformity on the continental shelf (Summerhayes et al., 1971). The projected trace of the South Atlas fault is, of course, generalized, and subsidiary fractures are to be expected. Dillon (1974) has demonstrated an en echelon pattern of magnetic anomalies south of the projected fault, trend which might be related to an overall fault system off southern Morocco.

seabed expression are restricted to a zone east of the overthrust complex (Figure 7). Within the allochthon salt diapirism is virtually confined to swells, none of which has pierced the Tertiary sequence. Such swells do not extend far to the west of the overthrust complex and the salt appears to pinch out east of Site 415 (Figure 3). There is no sign of salt cores in the tectonic folds in the distal apron (Figures 4 and 7). The diapiric-salt field (Figure 1) extends well north and south of the allochthon. Thus, whereas salt may have influenced the structure of the allochthon, it probably was not the prime cause of gravity sliding.

The large piercement diapirs east of the overthrust complex (Figure 6) have clearly been active features until very recently, as shown by their surface expression (Summerhayes et al., 1971). Rather than a cause of the allochthon, these diapirs are, I believe, an effect. They seem to have exploited preferentially a zone where overburden pressure was reduced by removal of sediments by gravity sliding.

\section{The Epeirogeny Hypothesis}

The apex of gravity sliding coincides with the strike continuation of the Atlas tectonic trend (Figure 9). Onshore the Atlas trend appears as a relative high of Lower Cretaceous and older rocks, flanked by younger depos- its (Ager, 1974; Figure 1). Isopach maps suggest that this West Atlas high emerged in Late Cretaceous time (Société Cherifienne des Pêtroles, 1966). Faunal studies of samples from an exploration well on the continental shelf off Agadir indicate a marked shallowing of the depositional environment on the southern flank of the high during the Late Cretaceous (Bhat et al., 1975). We therefore have evidence of the epeirogenic emergence of the western Atlas at the time of the gravity sliding on the outer margin.

The West Atlas high is bounded by two systems of east-west-striking folds (Ambroggi, 1963; Ager, 1974; Adams, 1976), the Jebel Amsitten anticline to the north and the Ida-ou-Tanane folds to the south (Figure 9). Adams (1976) has argued the case for a tectonic rather than a diapiric origin of these folds. Ager (1974) vividly describes standing on Cap Rhir watching the Ida-ouTanane folds plunge westward into the Atlantic and pondering the fate of the Atlas foldbelt where it meets the continental margin. The appearance of the same tectonic strike in the compressive $F^{2}$ folds beneath the outer part of the margin argues for their being part of the Atlas fold system. The onshore folds, particularly the Jebel Amsitten anticline, have asymmetric profiles (personal observation) and thus are similar to folds beneath the outer margin (e.g., Figure 8). 


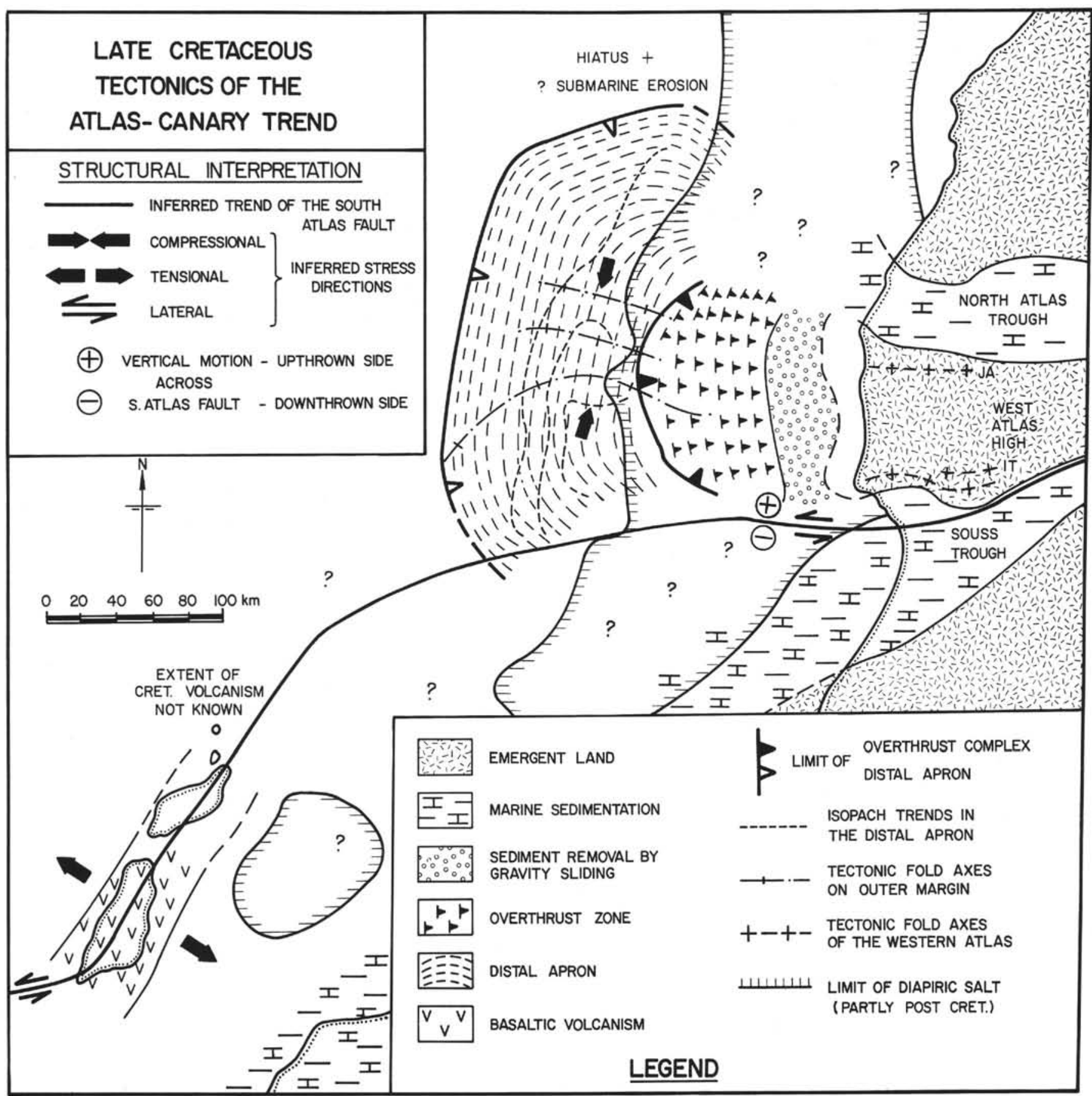

Figure 9. Part of the Glomar Challenger Leg 47 underway profile. The red horizon can just be mapped using ties with multichannel profiles for control. It shows a much more pronounced relief than younger horizons, and several folds appear to have an asymmetric profile.

Unfortunately, the timing of deformation in the High Atlas has not been studied in detail. Both Ambroggi (1963) and Faure-Muret and Choubert (1971) emphasize Tertiary deformation. However, the Liassic stretching and Kimmeridgian compression of the Alpide High Atlas trough (Du Dresnay, 1975) indicates a much longer history of tectonic activity along the trend. Ambroggi $(1963$, p. 302) mentions a Santionian epeirogenic event in the western High Atlas, which is locally manifested as a $10^{\circ}$ angular unconformity. $\mathrm{He}$ also documents a more subdued event at the end of the Campanian and his maps suggest a Cretaceous-Tertiary unconformity within the Ida-ou-Tanane fold system.

\section{Significance of the Allochthon}

The combination of DSDP drilling at Site 415 and seismic evidence sheds new light on the evolution of the Moroccan margin and in particular on the link between 
the High Atlas Mountains and the Canary Islands. It also has suggested wider implications for the interpretation of overthrust complexes exposed within orogenic belts.

\section{Late Cretaceous Tectonics Along the Atlas-Canary Trend}

Anguita and Herman (1975) remarked on the apparent correlation between Tertiary magmatic events on the Canary Islands and orogenic pulses in the Atlas. Robertson and Stillman (in press) have recently extended the active history of the islands back to Late Cretaceous time by describing, on Fuerteventura, a sequence of Lower Cretaceous sediments conformably overlain by post-Cenomanian basalts. These were folded before being intruded by Paleocene(?) or midEocene basic dikes. The Cretaceous basalts suggest extension across the Inner Canary Islands coincident with uplift, sliding, and folding along the Atlas trend (Figure 9).

Viewed on a broader scale, the Canary IslandsConcepcion Bank-Cap Tafelney area is but a kink in a continuous topographic high from the High Atlas orogen to the Canary Islands fracture zone (Figure 1). Contemporaneous basaltic volcanism and compressional folding in different parts of such a kink (Figure 9) suggest oblique tension and compression within an overall transcurrent-stress regime (e.g., Crowell, 1974). The South Atlas fault has been dubbed the geological boundary of Europe and Africa (Ager, 1974), and it would seem that its Late Cretaceous equivalent was affected by the relative movement of the European and African plates even if the main plate boundary lay farther north within the Rif-Betic system. Sea-floorspreading data from the North Atlantic (Pitman and Talwani, 1972) have been interpreted (Smith, 1971; Dewey et al., 1973) as indicating that between 110 and 80 million years ago Africa moved eastward relative to Europe, with a subsidiary component of north-south compression. The sinistral shear stress along the South Atlas fault implied by such a direction of relative motion is compatible with the observed compressional folding along the Atlas trend and tension on Fuerteventura (Figure 9), and with magnetic-anomaly patterns in the North Atlantic. Le Pichon et al. (1977) have demonstrated that a fit of the late Jurassic "magnetic quiet zone"' boundary south of the Canary Islands produces a $250-\mathrm{km}$ overlap farther north. One solution to this problem suggested by Le Pichon et al. is to invoke left-lateral movement along the South Atlas fault within the $148-80 \mathrm{Ma}$ interval.

Structural analyses of the folded Cretaceous sediments and lavas on Fuerteventura suggested to Robertson and Stillman (in press) that the folding was in response to a transcurrent-stress regime. Their limited data however suggest a dextral sense of motion. As the folding on Fuerteventura postdates the Cretaceous volcanism, which is explained here as part of a sinistralshear system, the two results are not incompatible and may be related to the postulated change in the relative motion of Europe and Africa at about $80 \mathrm{Ma}$ (late Late Cretaceous; Smith, 1971; Dewey et al., 1973). The dis- crepancy does, however, highlight the need for moredetailed studies of the history of the South Atlas fault.

\section{The Allochthon as an Analogue for Orogenic Complexes}

The continental margin described here can hardly be called entirely passive. Nonetheless it has undergone the development of an allochthonous thrust complex of considerable magnitude without an episode of subduction and plate convergence. Transcurrent movement, with perhaps only a limited offset, would probably be a sufficient driving force. The overthrusts beneath the Cap Tafelney terrace are of a scale and extent such that, were they exposed on land, they would rank as a significant structural unit. Analogous complexes might well exist in fossil marginal successions within orogenic belts. Very similar structures recently described off the Markan Coast in the Gulf of Oman were interpreted by White (1977) as originating in a subduction terrain.

Jansa et al. (1977) draw attention to the unusual preponderance of flysch sedimentation in the Cretaceous and Tertiary succession of the Moroccan Basin as compared with other North Atlantic margins. Drilling during our own Leg 50 at Site 416 (Site 416 report, this volume) served to emphasize this point, as we recovered core after core of a seemingly endless sequence of distal turbidites. The allochthon is overlain by more turbidites. Were it exposed on shore it would appear as a complex series of thrusts carrying exotic facies into a flysch succession which probably would have been modified by further faulting associated with its tectonic elevation. Such a sequence would not be out of place in the flysch basins of the Alps, of which the Moroccan Basin is, perhaps, only the most westerly.

\section{ACKNOWLEDGMENTS}

For the seismic data used in this study, I am indebted to Phillips Petroleum Company Limited, AGIP, Getty Oil Limited, The British Petroleum Company Limited, the BRPM in Rabat, Gulf Oil Limited, the West German Bundesanstalt für Geowissenschaften und Rohstoffe, and the Deep Sea Drilling Project. This paper is published with the consent of these companies and institutions. However, the interpretations made are my own and do not necessarily reflect the views of the organizations listed. Mr. C. E. Hallock of Phillips, Mr. R. K. Kirkbride of Gulf, and Dr. K. Hinz of BGR provided invaluable assistance in making available copies of the records involved.

Drs. R. J. Bailey, C. M. Barton, V. N. D. Caston, A. G. Smith, and N. H. Woodcock reviewed earlier drafts of the report, which greatly benefited from their comments, and from discussions with Mr. M. F. Melli, Mr. A. Mourabit, Dr. A. H. F. Robertson, and Ms. F. R. L. Lee, whose assistance with the interpretation of the seismic lines is gratefully acknowledged. I thank also Miss V. A. Muscutt, who typed the manuscript.

\section{REFERENCES}

Adams, A. E., 1976. The stratigraphy and sedimentology of Middle and Upper Jurassic limestones from southwest Morocco, Ph.D. Thesis, Univ. of Wales (Swansea).

Ager. D. V., 1974. The western High Atlas of Morocco and their significance in the history of the North Atlantic, Geol. Assoc. Proc., 85, p. 23-41. 
Ambroggi, R., 1963. Étude Géologique du versant Méricional du Haut Alas occidental et de la plaine du Souss, Notes Mém. Serv. Geol. Maroc. no. 157, p. 1-321.

Anguita, F. and Hernan, F., 1975. A propagating fracture model versus a hot spot origin for the Canary Islands, Earth Planet. Sci. Lett., v. 27, p. 11-19.

Beck, R. H. and Lehner, P., 1974. Oceans, new frontier in Exploration. Am. Assoc. Petrol. Geol. Bull., 58, p. 376-395.

Bhat, H., McMillan, H. J., Aubert, J., Porthault, B., and Surin, M., 1975. North American and African drift - the record in Mesozoic coastal plain rocks, Nova Scotia and Morocco. In Yorath, C. J. et al. (Eds), Canadian continental margins and offshore petroleum potential, Mem. Can. Soc. Petrol. Geol., 4, p. 375-389.

Crowell, J. C., 1974. Sedimentation along the San Andreas Fault, California. In Dott, R. H., Jr., and Shaver, R. H. (Eds.), Modern and ancient geosynclinal sedimentation: $S$. E. P. M. Spec. Publ., 19, p. 292-303.

Dewey, J. F., Pitman, W. C., Ryan, W. B. F., and Bonnin, J., 1973. Plate tectonics and the evolution of the Apline System, Geol. Soc. Am. Bull., v. 84, p. 3137-3180.

Dillon, W. P., 1974. Structure and development of the Southern Moroccan continental shelf, Mar. Geol., 16, p. 121-143.

Dillon, W. P. and Sougy, J. M. A., 1974. Geology of West Africa and Canary and Cape Verde Islands. In Nairn, A. E. M. and Stehli, F. G. (Eds.), The ocean basins and margins, v. 2, the North Atlantic. New York (Plenum Press), p. $315-390$.

du Dresnay, R., 1975. Influence de l'héritage structural tardihercynien et de la tectonique contemporaine sur la sédimentation jurassique, dans le sillon marin du Haut-Atlas, Maroc, IXth Int. Congr. Sedimentol., Nice, v. 4 p. 103-110.

Evans, I., Kendall, C. G. St. C., and Warne, J. E., 1974, Jurassic sedimentation in the High Atlas Mountains of Morocco during the early rifting of Africa and North America, Geology, v. 2, p. 295-296.

Faure-Muret, A. and Choubert, G., 1971. Le Maroc. Domaine rifain et atlasique. In Tectonique de l'A frique, Paris (UNESCO), p. 17-46.

Grunau, H. R., Lehner, P., Cleintaur, M. R., Allenbach, P., and Bakker, G., 1975. New radiometric ages and seismic data from Fuerteventura (Canary Islands), Maio (Cape Verde Islands) and Sao Tome (Gulf of Guinea). In Progress in geodynamics. Amsterdam (Roy. Neth. Acad. Arts Sci), p. $90-118$.
Le Pichon, X., Sibuet, J.-C., and Francheteau, J., 1977. The fit of the continents around the North Atlantic Ocean, Tectonophysics, v. 38, p. 169-209.

Mitchell-Thomé, R C., 1976. Geology of the Middle Atlantic Islands: Berlin (Gebrüder Borntraeger).

Moody, J. D. and Hill, M. J., 1956. Wrench fault tectonics, Geol. Soc. Am. Bull., v. 67, p. 1207-1246.

Jansa, L., Gardner, J. V., and Dean, W. E., 1978. Mesozoic sequences of the central North Atlantic - Stratigraphic synthesis. In Lancelot, Y., Siebold, E., et al., Initial Reports of the Deep Sea Drilling Project, v. 41: Washington (U. S. Government Printing Office), p. 991-1032.

Pitman, W. C. and Talwani, M., 1972. Sea-floor spreading in the North Atlantic, Geol. Soc. Am. Bull., v. 83, p. 619-696.

Robertson, A. H. F., and Stillman, C. J., in press. The sedimentary rocks of Fuerteventura, Canary Islands, and the evolution of the West African continental margin, J. Geol. Soc. London.

Sangree, J. B., Waylett, D. C., Frazier, D. E., Amery, G. B., and Fennessy, W, J., 1976. Recognition of continentalslope seismic facies, offshore Texas-Louisiana. In Bouma, A. H., Moore, G. J., and Coleman, J. M. (Eds.), Beyond the Shelf Break. AAPG Short Course (New Orleans) Course Notes: F1-F54.

Shipboard Scientific Party, 1977. Site 370: Deep basin off Morocco. In Lancelot, Y., Siebold, E., et al., Initial Reports of the Deep Sea Drilling Project, v. 41: Washington (U. S. Government Printing Office), p. 421-492.

Smith, A. G., 1971. Alpine deformation and the oceanic areas of Tethys, Mediterranean and Atlantic, Geol. Soc. Am. Bull., v. 82 , p. $2039-2070$.

Société Chérifienne des Pétroles, 1966. Le bassin du SudOuest Marocain. In Reyre, D. (Ed.) Bassins sédimentaires du Littoral Africain, Assoc. serv. géol. Africain Publ., p. 5-12.

Summerhayes, C. P., Nutter, A. H. and Tooms, J. S., 1971. Geological structure and development of the continental margin of northwest Africa, Mar. Geol., v. 11, p. 1-25.

Uchupi, E. Emery, K. O., Bowin, C. O. and Phillips, J. D., 1976. The continental margin off Western Africa: Senegal to Portugal, Am. Assoc. Petrol. Geol. Bull., v. 60, p. 809-878.

Warme, J. E., Schupbach, M. A., Evans, I., and Kendall, C. G. St. C., 1974. Structural framework and depositional history of the High Atlas Mountains, Morocco, $A A P G$ / SEPM, Ann. Mtg. Abs., v. 1, p. 95.

White, R. S., 1977. Recent fold development in the Gulf of Oman, Earth Planet. Sci. Lett., v. 36, p. 85-91. 